\title{
Japan's South China Sea Policy and Regional Subcomplex Expansion: Toward Free and Open Indo-Pacific
}

\author{
Rafyoga Jehan Pratama Irsadanar \\ Department of International Cooperation Policy Studies, Graduate School of International Cooperation Studies, Kobe University, Hyogo \\ Prefecture, Japan \\ irsadanar.rafyoga@gmail.com \\ Submitted: 30 January 2020; Revised: 2 August 2020; Accepted: 21 December 2020
}

\begin{abstract}
Abstrak
Penelitian ini bertujuan untuk menyelidiki motivasi Jepang untuk terlibat dalam sengketa Laut Cina Selatan. Dengan menggunakan metode penelitian kualitatif, penelitian ini menganalisis dokumen resmi Pemerintah Jepang dan literatur yang relevan untuk mencapai tujuan penelitian tersebut. Penelitian ini menemukan bahwa kepentingan utama Jepang di Laut Cina Selatan adalah untuk mengimbangi ekspansi Tiongkok dan menciptakan jalur maritim yang lebih aman demi terwujudnya Free and Open Indo-Pacific. Menggunakan kerangka regional security complex, penelitian ini melihat bahwa Jepang, dengan kehadirannya di Laut Cina Selatan, mencoba untuk meningkatkan interaksi keamanan dengan negara-negara Asia Tenggara untuk memperluas sub kompleks regional Asia Timur Laut, yang bertujuan untuk memperkuat persepsi Cina sebagai ancaman terhadap negara-negara Asia Tenggara. Keterlibatan di Laut Cina Selatan akan memperkuat hubungan keamanan Jepang dengan negara-negara Asia Tenggara yang dapat menyeimbangkan sifat ekspansif Tiongkok di Laut Cina Selatan, mempercepat terwujudnya visi Free and Open Indo-Pacific yang diprakarsai oleh Tokyo.

Kata kunci: regional security complex, Laut Cina Selatan, Jepang, Free and Open Indo-Pacific.
\end{abstract}

\begin{abstract}
This research aims to investigate Japan's motivation to be involved in the South China Sea dispute despite Japan's far distance from the conflicted area. Utilizing the qualitative research method, this research analyzes Japanese Government official documents and relevant literature to achieve the research objective. The research discovers that Japan's main interest in the South China Sea is to articulate a safer maritime lane for the sake of its Free and Open Indo-Pacific agenda by balancing China's assertiveness in the region. Employing a regional security complex framework, this research sees that Japan, by its presence in the South China Sea, tries to intensify the security interaction with Southeast Asian counterparts to expand the Northeast Asian regional subcomplex, aiming to strengthen the perception of China as a threat to Southeast Asian countries. The South China Sea involvement will fortify Japan's security interlink with Southeast Asian counterparts, balancing China's expansive trait in the maritime zone, accelerating Tokyo-initiated Free and Open Indo-Pacific vision.

Keywords: regional security complex, South China Sea, Japan, Free and Open Indo-Pacific.
\end{abstract}

\section{INTRODUCTION}

It is widely known that South China Sea is not part of Japanese territory, but only a few can grasp the fact that Japan is, to some significant extent, involved in the South China Sea maritime dispute (Drifte, 2016). Since Japan is neither a claimant nor directly threatened by China's nine-dash line in the South China Sea, what Japan looks for by involving itself in such a complicated dispute is interesting. Despite the anomaly, it can be seen that by Japan's participation in achieving South
China Sea stability, Prime Minister Shinzo Abe is aiming for a stronger Free and Open Indo-Pacific (FOIP) strategy by balancing China's assertiveness in the South China Sea.

The South China Sea, due to its high economic and geopolitical value, has been one of the most vital maritime zones around the world. Its strategic location as a major world shipping lane and abundant natural resources beneath the sea generated trade shipping 
activities valued at about $\$ 5.3$ billion, almost one-third of world maritime trade (Saiidi, 2018). Moreover, the sea has vast amount of natural resources and is a central sea lane for global shipment. Since the sea lane is highly strategic, it is also prone to over-lapping border claims, leading to regional instability. Since the 1970s, tension has been escalating due to China's nine-dash line claim over the South China Sea, which violates many Southeast Asian nations' sea sovereignty, such as the Philippines, Vietnam, Brunei and Malaysia. China, aiming to fortify its presence in the South China Sea, has built artificial military islands around Paracel and Spratlys Island, fully equipped with port facilities, navigating sensor arrays, runways, and bunkers for weapons (Stashwick, 2019). In response, the other claimant states have also deployed many military maneuvers to assert their border stance in the South China Sea, causing anxiety for many.

Outside major power, such as the United States, is also concerned about the stability within the region by arraying many militaries and naval operations in the maritime domain, such as Freedom of Navigation Operation (FONOP) in 2018 (LaGrone, 2018). Japan, as the United States' closest ally in Asia, is into the same narrative. Since Shinzo Abe's second term in 2012, Japan has established many security frameworks with Southeast Asian allies, especially under the ASEAN framework, as Storey (2013) stated. Those include, but are not limited to, defense equipment transfers, joint military training and human capacity building as the ASEAN Chairman stated during Manila ASEAN-Japan Summit in 2017:

“ASEAN noted Japan's constructive contributions to the development and regional cooperation, including through its "Free and Open Indo- Pacific strategy". We noted the importance of enhancing cooperation among maritime law enforcement agencies, such as capacity building assistance, joint exercises, information sharing, including Maritime Domain Awareness." (Duterte, 2017).

This research aims to investigate Japan's motivation to be involved in the South China Sea dispute by employing naval military activities and arranging security cooperation with Southeast Asians despite Japan's far distance from the conflicted area. Utilizing the qualitative research method, this research analyzes Japanese Government official documents, ASEAN communique and relevant literature to achieve the research objective. This paper argues that Japan's interest in the South China Sea is to accelerate regional peace and maritime stability as one main part of the Free and Open Indo-Pacific (FOIP) agenda. Employing a regional security complex framework, this paper explains that Japan, by its presence in the South China Sea, tries to intensify the security interaction with Southeast Asian counterparts to expand the Northeast Asian regional subcomplex, aiming to strengthen the perception of China as a threat to Southeast Asian countries.

\section{LITERATURE REVIEW}

The current literatures are mainly discussing the motivations of Japan and the method it employed to be involved in the South China Sea. The first group's main analysis is Japan's economic interest in the South China Sea as most of Japan's energy import and trade goes through the maritime lane. The other group mainly researches the potential actions Japan can take to delve into the dispute and draws policy suggestions for Japan in tackling possible domestic and international challenges.

Storey (2013) and Shoji (2014) both explained that Japan's main concern in the South China Sea is to contain China's assertiveness and encourage peaceful settlement. Storey (2013) found that Japan's interests in achieving stability in the South China Sea protect its trade flow in Southeast Asia and prevent China from weakening Asian nations' legal norms. Shoji (2014) then elaborated that Japan utilizes existing multilateral frameworks, especially with ASEAN, to inject maritime security issues to raise the awareness of the rule of law enforcement in the South China Sea. Two years later, Drifte (2016) discovered that Japan's decision to delve into the South China Sea is due to its connectivity with the East China Sea, where it directly clashes over Senkaku/Diayou Islands with China. The research also revealed that Japan was pushed to be more active in the 
South China Sea since Asian nations were anxious whether the United States was committed enough to balance China in the region.

While in a practical sense, Midford (2015) highlighted Japan's multilateralism and Official Development Assistance (ODA) utilization as the policy tool in forming South China Sea stability. Those ODAs were given to littoral states around the South China Sea, such as Indonesia, Philippines and Vietnam, to fortify the security of the vital maritime lanes, such as Lombok and Malacca Strait. The research also predicted that Japan would play a minimalist role in the dispute. In a more optimistic nuance, Koga (2018) said that Japan's South China Sea policy of capacity building and diplomatic enhancements has raised the confidence of Southeast Asian countries against China's pressure.

This article sees the bigger picture that East Asia and Southeast Asia have been more connected than before in terms of security issues since countries from both regions have gradually shared similar concerns and anxiety. By default, geographically East and the South China Sea are two directly connected parts forming the China Sea, making those the main gate for shipping lane distributing goods and energy supplies to Northeast Asian ports in Japan, China and South Korea (LaFond, 2017). Consequentially, the increasing connectivity of growing Southeast Asia and East Asia relies on the security of these seas. Therefore, many related actors are treating the South and the East China Sea issues in tandems as a connected whole, such as Japan that fortifies maritime security cooperation with ASEAN member states and the United States that particularly passed "The South China Sea and East China Sea Sanctions Act" to counter China's assertiveness (Shoji, 2014; Ghosh, 2019). However, the analysis of how these interlinks emerged is lacking. Using the regional security complex theory, this article aims to close the gap by elaborating on how Japan's South China Sea policy intensified the link of Northeast Asia security complex and Asia security subcomplex in Southeast Asia.

\section{THEORETICAL FRAMEWORK}

This research employed the regional security complex theory initiated by Barry Buzan to answer the research question. There is a fundamental and expanded definition of what a security complex is. Initially, a security complex was defined as "a set of states whose major security perceptions and concerns are so interlinked that their national security problems cannot reasonably be analyzed or resolved apart from one another" (Buzan, Wæver, \& Wilde, 1998). This definition was then expanded to be "a set of units whose major processes of securitization, desecuritization, or both, are so interlinked that their security problems cannot reasonably be analyzed or resolved apart from one another" (Buzan, Wæver, \& Wilde, 1998). From those definitions, it can be seen that the main spirit of a security complex is the common and contingent security issues among the states within the complex. Therefore, this theory also argues that security is socially constructed, and there must be a securitizing actor initiating the definition of certain critical and threatening conditions that requires prompt responses (Buzan, 2003).

To form a security complex, three main components are required: (1) the structure of the units; (2) the amity and enmity formation; and (3) the power distribution among the major units (Buzan, 2003). These metrics can be used to analyze whether some changes occur within the regional security complex. Buzan (2003) elaborated four ways to evaluate the regional security complex shift:

- Maintenance of status quo. As the name says, the three major components are persisted to maintain their initial form. Despite the least tangible change, it does not mean that there was no change. The change did occur but least impactful to the structure.

- Internal transformation. It can be inferred that there is an internal change within the border of the local complex.

- External transformation. Such transformation occurs when there is an expansion or a contraction of its existing outer boundary. It might include new states or exclude the existing states from the current complex.

- Overlay. It means that there are one or more 
external power(s) moving into the regional complex causing a drastic shift within the boundary.

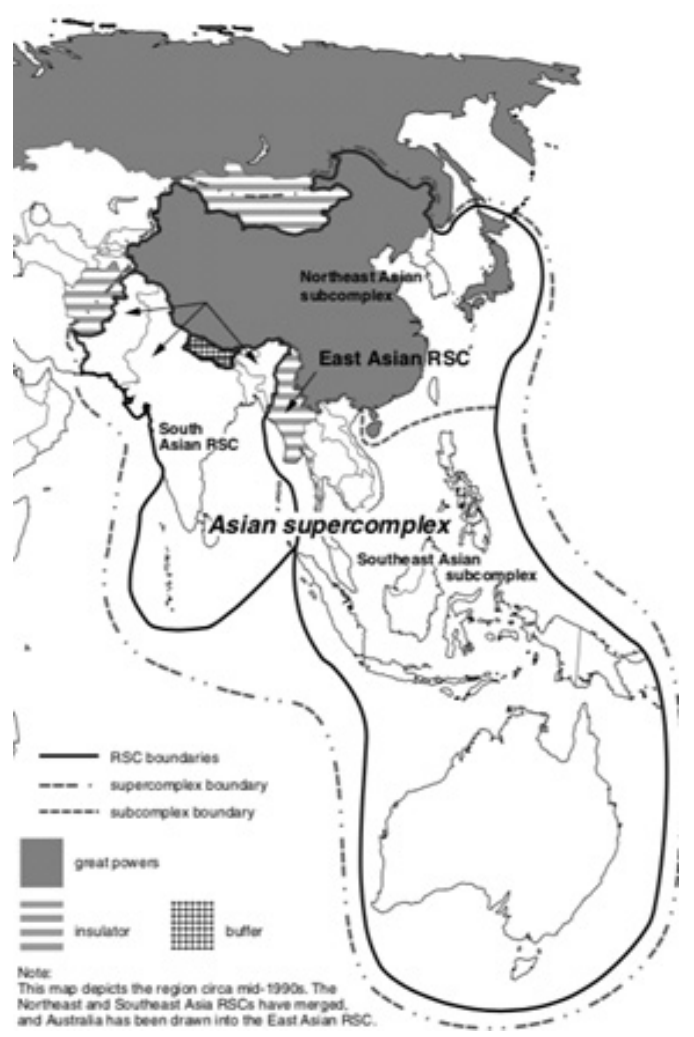

Figure 1. Asian Security Supercomplex Pattern (Buzan \& Wæver, 2003)

Referring to Figure 1, the theory was utilized to frame Japan's security policy to the South China Sea as an external transformation of Northeast Asia regional subcomplex by expanding its southern boundary beyond the East China Sea to the South China Sea. The metrics of essential components then evaluated whether Japan has created some changes in the security complex. The structure explained in this paper comprises South China Sea claimants (Vietnam, Philippines, Brunei and Malaysia), China, and outside powers (Japan and the United States).

\section{RESEARCH METHOD}

As highlighted earlier, this research seeks to understand Japan's foreign policy decision to engage the South China Sea dispute. To achieve the objective, the research was done using qualitative method with disciplined configurative case studies approach. The mentioned approach of case studies aims to explain a certain event or phenomena using an established theory (George \& Bennett, 2005). In answering the research question, this article presented official documents from related governments, reliable literatures, and press statements by relevant stakeholders. The amassed data then analyzed using an established theory, which is Regional Security Complex Theory (RSCT). The specified detail about the theory is mentioned in the following subsection.

\section{RESULT AND ANALYSIS FREE AND OPEN INDO-PACIFIC: SIGNIFICANCE FOR JAPAN}

This research sees that the grand interest of Japan in its South China Sea policy is to accelerate the realization of the Free and Open Indo-Pacific (FOIP) vision. FOIP, as its name states, is an idea where sustainable prosperity can be achieved by linking two continents (Asia-Africa) and two oceans (Indo-Pacific), with ASEAN as the bridge connecting the two as it is geopolitically positioned in between (Ministry of Foreign Affairs of Japan, 2019). Introduced by Shinzo Abe in 2016 during Tokyo International Conference on African Development (TICAD) in Nairobi, Kenya, on August 27th, 2016, this strategy is seen to be significant in expanding the economic zone stimulating free trade and investment (Aizawa, 2018). Shinzo Abe (2016) also stated in his speech:

"Japan bears the responsibility of fostering the confluence of the Pacific and Indian Oceans and of Asia and Africa into a place that values freedom, the rule of law, and the market economy, free from force or coercion and making it prosperous."

The success of this agenda is significant for Japan since its economic growth is mainly reliant on access to foreign markets and supplies through Asia, the Middle East and 
Africa nexus (Brown, 2018). Not to mention that Japan is also struggling to revitalize itself economically; thus, the uninterrupted progress of this geo-economic agenda has become even more important for Japan. Other than that, Japan's energy supply is $80 \%$ imported, making the safety of maritime interconnectivity vital for Japan's survival (Ministry of Foreign Affairs of Japan, 2004). Therefore, intercontinental connectivity is essential for Japan, even without the FOIP agenda.

However, FOIP vision will be restrained from becoming truly lucrative if Southeast Asia, as the vital post, is unstable. The stability in Southeast Asian maritime ground, namely the South China Sea, is vital since it is the main export-and-import shipping lane and energy supplies in that region that many states are relying upon. In addition to the reliance of many major economies such as Japan and South Korea on the South China Sea for trade, the maritime domain is also crucial for Southeast Asians as it employs 3.7 million people producing 12\% of world fishery supplies (Mastro, 2020). On the other hand, the stability required to achieve FOIP is challenged by China's assertiveness, leading many surrounding states to feel insecure (Szechenyi \& Hosoya, 2018). The nine-dash line claimed by China has escalated the military activities in the South China Sea, prone to maritime confrontation among the conflicting states. Despite China being ambiguous and somewhat reluctant to assert the legal argument of the nine-dash line, China has bold military measures in defending it. China has two goals in the South China Sea, which are to "maintain the stability" and "protecting their rights" in the maritime domain (Zhang, 2017). China has conducted a series of military activities in the disputed area, such as naval drills and training on an "unusually large scale" with carrier ships in 2018 (Pearson \& Torode, 2018). Not only that China flexes its military power, it also projects administrative bargaining by establishing artificial military islands around the Spratly Islands in the South China Sea (Mangosing, 2018). Such measures taken by China caused growing insecurities among Southeast Asian countries as it breached their maritime sovereignty and caused many naval standoffs within the troubled waters (Pearson, 2020). The volatile shipping lane may discourage trade activities through Southeast Asia, jeopardizing the benefit targeted by the FOIP agenda in expanding the lucrative economic sphere in the Indo-Pacific. Therefore, containing China is one major FOIP mission concerning stability.

\section{JAPAN INTENSIFIED SOUTHEAST ASIA SECURITY ENGAGEMENT: SUBCOMPLEX EXPANSION}

Examined with regional security complex theory, this paper argues that Japan tries to expand the Northeast Asia subcomplex southward, creating external expansion. As mentioned in the theoretical framework, it requires three major elements to form a security complex; (1) the structure of the units; (2) the amity and enmity formation; and (3) the power distribution among the major units (Buzan, 2003).

First, it fulfills the requirement of unit structures forming a system similar to the global one; Southeast Asia is anarchical. There is no governing rule in the South China Sea that can guarantee any country to comply with rules, not even international law, as China is not opting to obey it to begin with. To create a balance of power, many outside powers, such as the United States and Japan, have been present in Southeast Asia for that purpose. In addition, Japan and China have been integrating into Southeast Asia's regional structure since both are in a tight rivalry in investment, economy, politics and security. Buzan \& Wæver (2003) referred to Waltz's 1979 work to define the idea of structure. By this Waltzian view, the structure is defined as how the units are arranged and placed within a system. In international politics, the units forming the structure are states. Contextualized with this specific South China Sea case, the units are states involved in the dispute, and those are Southeast Asian states, Japan, China and the United States. ASEAN is indeed an inseparable entity from the discourse. However, the primary gravity is more on how the Association's actions serve the member states' interest rather than on how ASEAN works as an international organization deciding for itself. Therefore, ASEAN is still part of the discourse, but the units are still the member states. 
Second, Japan and Southeast Asian nations, represented by ASEAN, have agreed that the unilateral actions by China are a threat against the regional stability. Vietnam, which is the 2020 Chair of ASEAN representing the 10-members bloc, during the 36th ASEAN Summit, delivered the Association's stance to stick with the 1982 United Nations Oceans Treaty in an opposing manner to China's claim (The Guardian, 2020). Therefore, Southeast Asian nations viewed Japan's security involvement in the region as a contributive one (Duterte, 2017). In a security context, under Abe Doctrine, Japan has been pursuing security cooperation with Southeast Asian counterparts to balance China, in which favorable response was given in return to Japan's security initiatives (Nguyen, 2016). Under the Shinzo Abe administration, Japan has deployed its first defense initiative to Southeast Asia, termed Vientiane Vision, to fortify Japan's regional security role in the region (Parameswaran, 2019). Under this initiative, Japan and Southeast Asian counterparts have carried out many agendas such as joint exercises, human development programs and defense industry cooperation. In this sense, Japan's security engagement has created an amity and enmity formation. United Nations Oceans Treaty in an opposing manner to China's claim (The Guardian, 2020). Therefore, Southeast Asian nations viewed Japan's security involvement in the region as a contributive one (Duterte, 2017). In a security context, under Abe Doctrine, Japan has been pursuing security cooperation with Southeast Asian counterparts to balance China, in which favorable response was given in return to Japan's security initiatives (Nguyen, 2016). Under the Shinzo Abe administration, Japan has deployed its first defense initiative to Southeast Asia, termed Vientiane Vision, to fortify Japan's regional security role in the region (Parameswaran, 2019). Under this initiative, Japan and Southeast Asian counterparts have carried out many agendas such as joint exercises, human development programs and defense industry cooperation. In this sense, Japan's security engagement has created an amity and enmity formation.

Third, penetration of Japan, along with its closest ally, the United States, to the South China Sea conflict does change the power distribution in Southeast Asia, balancing the rise of China in the region. Both Japan and the United States are similarly concerned about China's expansionism in the region, both in the East and the South China Sea, thus aiming to contain it (Ministry of Foreign Affairs of Japan, 2019). Japan's actions in the South China Sea have redistributed the power within the structure as it improved other units' military capabilities. In this sense, the Regional Complex Security Theory mixes the neorealist and constructivist approaches to analyze power distribution (Buzan \& Wæver, 2003). In the constructivist lens, the distribution is defined as how the enmity and amity are constructed, in tandem and as the first point explained. In the neorealist perspective, the power is distributed structurally by material powers that the units have. This third part elaborates on the neorealist part of the power distribution, in particular, in the military context.

The first signal of Japan's interest in being involved in the South China Sea emerged as Japan initiated many security cooperation with Southeast Asian nations, especially the claimants aiming to strengthen alliances for balancing China in the South China Sea, as Nguyen (2016) explained. Japan has weaponized its Southeast Asian counterparts by donating aircraft and vessels as maritime defense equipment in the South China Sea. Since Japan lifted its military export ban in 2014, it donated six patrol boats to Vietnam (Hiep, 2017), five units of patrol aircraft to the Philippines (Parameswaran, 2017), and would lease other units of vessels to Indonesia (Ministry of Foreign Affairs of The Republic of Indonesia, 2020). It was mentioned that Japan had its first defense initiative to ASEAN called Vientiane Vision, aiming to strengthen maritime ties with and fortify the capacity of ASEAN nations. Furthermore, Japan has also conducted military exercises in Malacca Strait with the United States to fortify its Free and Open Indo-Pacific vision as Malacca Strait is the chokepoint between the Indian Ocean and Pacific Ocean (Panda, 2019). In addition to providing weaponries and holding exercises, Japan has built maritime infrastructures to maintain security, such as establishing radar stations in the Sulu Celebes Islands to prevent piracy (Kelly \& Kubo, 2017). Japan's involvement in the South China Sea dispute is a 
strategic move to fortify its alliance with Southeast Asian nations as political capital to balance China in the South China Sea. Japan's maneuver to collaborate with ASEAN in balancing China can be explained as ASEAN strategic importance has been escalating for Japan in recent years, as Japan Prime Minister Shinzo Abe stated in his speech during an official visit to Southeast Asia in 2013:

"I will push forward with strategic diplomacy that contributes to both Japan's national interests and the peace and prosperity of the region and the world. ASEAN is an important partner in fostering the stability and prosperity of the Asia-Pacific region, and Japan will place importance on ASEAN going forward in terms of both economic growth and security."

ASEAN geopolitical value as the native of South China Sea territory is an essential metric on how ASEAN importance advances among conflicting parties. Therefore, strengthening the tactical alignment with ASEAN, the host regional organization in Southeast Asia, will be significant to minimize Beijing's expansion in the South China Sea.

Along with the geographical consideration, Japan's engagement with Southeast Asian nations is also caused by the fact that China similarly threatens many maritime grounds, such as the Philippines, Vietnam, Malaysia, and Brunei Darussalam. It gives an urgent reason for Japan and those Southeast Asian claimants (along with ASEAN as its regional organization) to cooperate as their political interests are now related. Despite being an outsider of the South China Sea, Japan also fights for its survival against China in the Senkaku/Diayou battle in the East China Sea. This crisis has engaged Southeast Asia and ASEAN to strengthen maritime Asia, vital to the Japanese diplomatic agenda under Shinzo Abe's administration (Pajon, 2013). Intensifying the alliance with ASEAN is a step toward balancing China in championing the FOIP agenda.

Having a stronger tie with Southeast Asian counterparts is undoubtedly not enough to achieve the Free and Open Indo-Pacific vision. Therefore, Japan's presence in the dispute also aims to fortify the United States primacy in the South China Sea, according to
Sato's 2018 study. As one of the closest allies in Asia, the United States encourages Japan to intensify its participation in maintaining the peace and stability in the region since Japan's presence will contribute to more stability in the region, as Kelly \& Kubo stated in 2015. It is in line with Shinzo Abe's New Five Principles introduced in 2013, aiming to foster cooperation to maintain the maritime security in the region with ASEAN, reaffirming its favor to the United States, thus rebalancing the Asia-Pacific agenda (Abe, 2013). By Japan's stronger presence in the South China Sea, both direct and indirect, it is expected to strengthen the long-lasting Japan-United States security alliance as the main spearhead to contain China's assertiveness in the South China Sea, expecting to bring more stability.

Japan and the United States have a lot of similar and intersecting strategic interests in a general context. Tokyo and Washington are actually within the same boat concerning the Free and Open Indo-Pacific vision. Beyond the bilateral alliance, Japan and the United States are two of four countries calling themselves "the Quad". The Quad is a name given for Free and Open Indo-Pacific agenda pioneering countries consisting of Japan, United States, India and Australia.

After ten years of hiatus since Shinzo Abe's initial proposal in 2007, all of the Quad states were committed to revive the security dialogue during ASEAN Summit Manila 2017 and motivated to contain the ambition of China to dominate Asia through its Belt and Road Initiative Program and expansive behavior in South China Sea (Howell, 2018). Since Japan and the United States, along with the other Quad members, are major maritime powers with high reliance on the Indian and Pacific Ocean, the strategic partnership will be likely to progressively grow. By default, Indo-Pacific is the economically prospective region where the world's three largest economies (United States, China and Japan) are located, making it possible to be the new center of the world economic hub. It is the huge economic sphere they are fighting for, as the United States stated the maritime domain as "the single most consequential region for America's future" (The Department of Defense of United States of America, 2019). The Quad member states are 
also expressing their strong interest in cooperating in developing their infrastructure projects before China's Belt and Road Initiative takes full domination ( $\mathrm{He} \&$ Mingjang, 2020). This type of tight bond clarifies the similar interest Japan and United States share, both in containing China in the South China Sea and achieving the Free and Open Indo-Pacific. In addition, the United States' Department of Defense also stated that the Free and Open Indo-Pacific under the Trump administration will be executed by strengthening the strategic cooperation with key allies in Asia, such as Japan (Silverberg \& Sullivan, 2019). Thus, a solidified presence in the South China Sea will help Tokyo maintain Washington's presence in the region as deterrence against China.

The main metric of a security complex is the interlinked security concerns. Japan has been intensifying its security engagement in Southeast Asia, especially since Shinzo Abe assumed office in 2012. The dispute in the South China Sea has given the conservative Shinzo Abe a stronger justification to employ militaristic domestic and foreign policies, especially to Southeast Asia. For decades, Japan's approach to Southeast Asia has been gravitated around an economic approach, both in transactional activities such as investment and trade as well as in official development assistance. Fukuda Doctrine, introduced by Prime Minister Takeo Fukuda in 1977, aims to convince Southeast Asia that Japan is an "equal partner" that aims to build a "heart-to-heart" relationship and to "exclude military element" in their relationship (Er, 2013). However, a major shift in foreign policy occurred following Shinzo Abe's introduction of his new security-oriented grand strategy, famously known as Abe's Doctrine. Boldly different from Fukuda Doctrine, this Doctrine is driven by the ambition to be more proactive in international security, especially by the closer ties with Southeast Asian counterparts as a containment strategy against China (Fukuda, 2015). Introduced to the ASEAN audience in 2013, Shinzo Abe openly expressed its motivation to fortify maritime security in Asia and support the United States presence in the region (Abe, 2013). As a result, the security issues around Southeast and Northeast Asia have been more interlinked due to Japan's initiatives, especially concerning the South China Sea.

As RSCT emphasizes on neorealist view on structure, Japan's actions to stretch its military muscles further to Southeast Asia are a reaction toward structural necessity. As Japan's closest ally in the structure, United States, is declining, it needs to equip itself with more flexibility to engage with other countries in security aspects to cover up the missing power in Southeast Asia (Sakaki, 2015). In a more specific Southeast Asia context, Arase (2019) explained that China's Belt and Road Initiative (BRI) and increasing naval presence in the region threaten Japan's interest. However, Japan cannot act freely due to domestic and international constraints, and it needs to cooperate with other countries to create collective actions in countering China's revisionist agenda.

Beyond establishing stronger security cooperation, Japan's maneuver in the South China Sea also includes the securitization of China as a threat to regional stability, which is the major element of a security complex. Besides numerous statements in the Japanese Defense White Book and Diplomatic Blue Book, Shinzo Abe also warned that China might make the South China Sea "Lake of Beijing", framing China's flex in the maritime domain ominous (Holmes, 2013). Japan might not be the sole and direct reason other Southeast Asian countries see China's unilateral actions in the South China Sea as a threat, but the issue of the South China Sea has always been in the high-summits where Japan and Southeast Asian countries are in, such as ASEAN Regional Forum. In response, as mentioned earlier, not just Southeast Asian countries adopted many policies to protects their seas from China. Those countries also cooperate with Japan in doing so.

Japan's main motivation to intensively engage with Southeast Asia has been to protect its Free and Open-Indo Pacific agenda. This article supports the argument by presenting the idea that Japan's South China Sea policy has expanded Northeast Asia security subcomplex southward by securitizing China among Southeast Asian audiences. It will be easier for Japan to stabilize Southeast Asia linchpin connecting the Indian 
Ocean and the Pacific Ocean. ASEAN, initiated by Indonesia, then drafted "ASEAN Outlook on Indo-Pacific" to catch up with the Free and Open Indo-Pacific by establishing the ASEAN version of the Indo-Pacific strategy (Saha, 2019). Even though the Outlook, when it was published in 2019, was still seen to be premature, it showed that ASEAN was urged to express its motivation not to be left out in the rapid Indo-Pacific conversation (Parameswaran, 2019). Within the Outlook official release, ASEAN showed its concern to the maritime awareness in the region and its commitment to use the existing multilateral framework such as East Asia Summit and ASEAN Regional Forum to address strategic issues. Despite the fact that ASEAN Outlook on Indo-Pacific is multidimensional, this multilateral aspect of the Outlook is dominated by maritime and security frameworks as mentioned below:

"ASEAN Outlook on the Indo-Pacific involves the further strengthening and optimization of ASEAN-led mechanisms, including the East Asia Summit (EAS), the ASEAN Regional Forum (ARF), the ASEAN Defense Ministers Meeting Plus (ADMM-Plus), the Expanded ASEAN Maritime Forum (EAMF) and others such as the relevant ASEAN Plus One mechanisms." (ASEAN, 2019).

This paper sees a similar concern that Japan still tries to securitize the South China Sea issue to the Southeast Asian audience to maintain support against China in the South China Sea. In evidence, Japan shows its enthusiasm and support to this Outlook, as Foreign Minister Motegi stated during his visit to ASEAN in early 2020:

"Why does Japan support the AOIP? It is primarily because the future image of the Indo-Pacific indicated in the AOIP has much in common with what Japan envisions as the future of the Indo-Pacific. The Indo-Pacific is the core of global dynamism, inhabited by half of the world's population. At the same time, the balance of power is now rapidly changing there, with various actors interacting with one another in an intertwined manner." (Motegi, 2020).

The foreign minister's statement also emphasized to the ASEAN audience that there is an urgency to maintain the balance of power in the region, which can be interpreted as balancing China, as it is the only party with unilateral actions. This assertion is also supported by the following statement of Foreign Minister Motegi:

"Particularly, in the waters of this region, which are public goods for the entire international community, all states must act, and their rights must be entitled in accordance with the basic principles of the international law of the sea, like freedom of navigation and all disputes regarding the seas must be settled peacefully. It is only by meeting these preconditions that this region can enjoy genuine prosperity as the hub of the sea lanes." (Motegi, 2020).

The follow-up statement confirms that the balance of power that Japan implies that the focus of Indo-Pacific includes the South China Sea dispute since it is the most problematic sea waters in Southeast Asia.

\section{CONCLUSION}

As expressed, Japan's engagement in the South China Sea dispute aims to accelerate a grand vision in maximizing Free and Open Indo-Pacific advancement for regional peace and maritime stability. As FOIP's leading spirit is inter-continental connectivity, this agenda is essential for Japan's wellbeing due to its high reliance on business with foreign partners across the world. Utilizing regional security complex theory, this research recognizes Japan's maneuver in the South China Sea as part of external transformation expanding Northeast Asia subcomplex southward to Southeast Asia subcomplex, aiming to strengthen China securitization in Southeast Asia. Japan's policy to be present in the South China Sea dispute fortified its alliance with Southeast Asian nations as the native of the region. Strengthening bonds with Southeast Asia and ASEAN will help Japan securitize and balance China as a step for FOIP realization. Japan's South China Sea policies also deepen its alliance with the United States, as both states are united within "The Quad" alliance as FOIP initiators. As the Japan-United States alliance can work as a deterrent against China, fostering relations with Washington will help Tokyo contain Beijing's expansion in maritime Asia. As a result, ASEAN then established its Outlook on Indo-Pacific, which is very coherent with Japan's agenda in Southeast Asia on creating maritime stability, especially in the South China Sea. 


\section{REFERENCE}

Abe, S. (2013, July 27). Press Conference by Prime Minister Shinzo Abe during His Visit to Southeast Asia. Retrieved May 20, 2019, from from Prime Minister of Japan and His Cabinet: https://japan.kantei.go.jp/96_abe/statement/201307/27kai ken_e.html

Abe, S. (2013, July 27). Press Conference by Prime Minister Shinzo Abe during His Visit to Southeast Asia. Retrieved May 23, 2019, from Prime Minister of Japan and His Cabinet Website: https://japan.kantei.go.jp/96_abe/state ment/201307/27kaiken e.html

Abe, S. (2013, January 18). The Bounty of the Open Seas: Five New Principles for Japanese Diplomacy. Retrieved June 7, 2019, from Ministry of Foreign Affairs of Japan: https://ww w.mofa.go.jp/announce/pm/abe/abe_0118e.html

Abe, S. (2016, August 27). Address by Prime Minister Shinzo Abe at the Opening Session of the Sixth Tokyo International Conference on African Development (TICAD VI). Retrieved June 7, 2019, from Japan Ministry of Foreign Affairs: https://www.mofa.go.jp/afr/af2/page4e_000496.html

Aizawa, T. (2018). The Philosophy and Practice of the Free and Open Indo-Pacific Strategy (FOIP). From the Oceans : Intelligence Analysis (Special Edition), 1-15.

Arase, D. (2019). Japan's Strategic Balancing Act in Southeast Asia. ISEAS Perspective, 1-10.

ASEAN. (2019, June 23). ASEAN Outlook on the Indo-Pacific. Retrieved June 5, 2019, from ASEAN: https://asean.org/stor age/2019/06/ASEAN-Outlook-on-the-Indo-Pacific_FI NAL 22062019.pdf

Brown, J. D. (2018, April 3). Japan's Indo-Pacific strategy falls short. Retrieved June 7, 2019, from The Japan Times: https://www.japantimes.co.jp/opinion/2018/04/03/commen tary/japan-commentary/japans-indo-pacific-strate gy-falls-short/\#.XeXiCi2B2fR

Buzan, B. (2003). Regional Security Complex Theory in the Post-Cold War World. In F. Söderbaum, \& T. M. Shaw, Theories of New Regionalism (pp. 140-159). London: Palgrave Macmillan.

Buzan, B., \& Wæver, O. (2003). Regions and powers: The Structure of International Security. New York: Cambridge University Press.

Buzan, B., Wæver, O., \& Wilde, J. d. (1998). Security: A New Framework for Analysis. London: Lynne Rienner Publishers.

Drifte, R. (2016). Japan's Policy towards the South China Sea Applying "Proactive Peace Diplomacy"? Peace Research Institute Frankfurt Report, 1-31.

Duterte, R. (2017, November 26). Chairman's Statement of the 20th Asean-Japan Summit. Retrieved June 7, 2019, from Association of Southeast Asian Nations (ASEAN): http://ase an.org/storage/2017/11/20th-ASEAN-Japan-Sum mit-Chairs-Statement-FINAL.pdf

Er, L. P. (2013). The Fukuda Doctrine: Origins, Ideas, and Praxis. In L. P. Er, Japan's Relations with Southeast Asia: The Fukuda Doctrine and Beyond (pp. 10-23). London and New York: Routledge.

Fukuda, T. (2015). Japan's New ASEAN Diplomacy? Why the Abe Doctrine May Be Counterproductive. Toyo Eiwa University Time Review Paper (時評論文), 23-29.
George, A. L., \& Bennett, A. (2005). Case Studies and Theory Development in the Social Sciences. Massachusetts: MIT Press.

Ghosh, N. (2019, May 24). US Bill reintroduced to deter China in South China, East China seas. Retrieved July 1, 2019, from The Strait Times: https://www.straitstimes.com/world/unit ed-states/bill-introduced-to-deter-china-in-south-chi na-east-china-seas

He, K., \& Mingjang, L. (2020, February 7). Four reasons why the Indo-Pacific matters in 2020. Retrieved June 5, 2019, from Oxford University Press Blog: https://

blog.oup.com/2020/02/four-reasons-why-the-indo-pacif ic-matters-in-2020/

Hiep, L. H. (2017). The Strategic Significance of Vietnam-Japan Ties. ISEAS Perspective, 1-8.

Holmes, J. R. (2013, January 7). The South China Sea: "Lake Beijing". Retrieved June 7, 2019, from The Diplomat: https://thediplomat.com/2013/01/the-south-chi na-sea-lake-beijing/

Howell, D. (2018, March 2). Is the Quad the new Trump card? Retrieved June 3, 2019, from The Japan Times: https://ww w.japantimes.co.jp/opinion/2018/03/02/commen tary/world-commentary/quad-new-trump-card/\#.XeYwry 2B2fQ

Kelly, T., \& Kubo, N. (2017, November 10). Japan to build four radar stations for the Philippines to counter piracy surge: sources. Retrieved July 1, 2019, from Reuters: https://ww w.reuters.com/article/us-japan-philippines-radar/ja pan-to-build-four-radar-stations-for-the-philip pines-to-counter-piracy-surge-sources-idUSKBN1DA0A5

Koga, K. (2018). Japan's strategic interests in the South China Sea: beyond the horizon? Australian Journal of International Affairs, 16-30.

LaFond, E. C. (2017, May 1). East China Sea. Retrieved July 1, 2019, from Encyclopædia Britannica: https://www. britanni ca.com/place/East-China-Sea

LaGrone, S. (2018, March 28). U.S. Warship Sails Past Disputed South China Sea Artificial Island in Freedom of Navigation Mission. Retrieved June 3, 2019, from USNI News: https://news.usni.org/2018/03/23/u-s-warship-sails-past-dis puted-south-china-sea-artificial-island-freedom-naviga tion-mission

Mangosing, F. (2018, February 5). EXCLUSIVE: New photos show China is nearly done with its militarization of South China Sea Read more: https://www. inquirer.net/specials/exclu sive-china-militarization-south-china-sea\#ixzz6TBaavKdo Follow us: @inquirerdotnet on Twitter | inquirerdotnet o. Retrieved July 1, 2019, from Inquirer.net: https://www.in quirer.net/specials/exclusive-china-militarization-south-chi na-sea

Mangosing, F. (2018, February 5). EXCLUSIVE: New photos show China is nearly done with its militarization of South China Sea. Retrieved July 1, 2019, from Inquirer.net: https://ww w.inquirer.net/specials/exclusive-china-militariza tion-south-china-sea

Mastro, O. S. (2020, May 21). Military Confrontation in the South China Sea. Retrieved July 27, 2020, from Council on Foreign Relations: https://www.cfr.org/report/military-confronta tion-south-china-sea 
Midford, P. (2015). Japan's Approach to Maritime Security in the South China Sea. Asian Survey, 525-547.

Ministry of Foreign Affairs of Japan. (2004, April). Strategy and Approaches of Japan's Energy Diplomacy. Retrieved December 27, 2017, from Japan's Ministry of Foreign Affairs: http://www.mofa.go.jp/policy/energy/diploma cy.html

Ministry of Foreign Affairs of Japan. (2019, April 19). Joint Statement of the Security Consultative Committee. Retrieved July 6, 2019, from Ministry of Foreign Affairs of Japan: https://www.mofa.go.jp/files/000470738.pdf

Ministry of Foreign Affairs of Japan. (2019, November). Towards Free and Open Indo-Pacific. Retrieved July 11, 2019, from Japan Ministry of Foreign Affairs: https://www.mofa.go.jp/ files/000407643.pdf

Ministry of Foreign Affairs of The Republic of Indonesia. (2020, January 10). Japan is Committed to be a Key Partner in the Development of Indonesia's Priority Sector. Retrieved July 11, 2020, from Ministry of Foreign Affairs of The Republic of Indonesia: https://kemlu.go.id/portal/en/read/954/berita/ jepang-berkomitmen-menjadi-mitra-kunci-pembangu nan-sektor-prioritas-indonesia

Motegi, T. (2020, January 10). ASEAN Policy Speech by Foreign Minister MOTEGI Toshimitsu : "Towards a new stage of cooperation in the spirit of Gotong-Royong". Retrieved July 11, 2020, from Ministry of Foreign Affairs of Japan: https://www.mofa.go.jp/s sa/sea2/page3e 001148.html

Nguyen, P. (2016, March 17). Southeast Asia Dances to the Tune of Japan's Abe Doctrine. Retrieved December 24, 2017. from Center for Strategic and International Studies : https://www.csis.org/analysis/southeast-asia-dances-tune-ja pan's-abe-doctrine

Nguyen, P. (2016, March 17). Southeast Asia Dances to the Tune of Japan's Abe Doctrine. Retrieved November 3, 2017, from Center for Strategic and International Studies : https://ww w.csis.org/analysis/southeast-asia-dances-tune-ja pan's-abe-doctrine

Pajon, C. (2013, December 6). Japan's "Smart" Strategic Engagement in Southeast Asia. Retrieved December 7, 2017, from Asan Institute for Policy Studies: http://ww w.theasanforum.org/japans-smart-strategic-engage ment-in-southeast-asia/\#3

Panda, A. (2019, May 21). US, Japan Conduct Cooperative Naval Deployment in Strait of Malacca. Retrieved September 2, 2019, from The Diplomat: https://thediplo mat.com/2019/05/us-japan-conduct-cooperative-naval-de ployment-in-strait-of-malacca/

Parameswaran, P. (2017, October 31). Why Japan's New Military Japan's Asia Security Role into Focus. Retrieved July 27, 2020, from The Diplomat: https://thediplo mat.com/2019/11/vientiane-vision-2-0-puts-japans-asia-se curity-role-into-focus/

Pearson, J. (2020, June 26). Amid pandemic, SE Asian nations warn of 'alarming' South China Sea incidents. Retrieved July 22, 2020, from Reuters: https://www.reuters.com/arti cle/us-asean-summit/amid-pandemic-se-asian-na tions-warn-of-alarming-south-china-sea-incidents-idUSK BN23X1F8

Pearson, J., \& Torode, G. (2018, March 27). Exclusive: Satellite images reveal show of force by Chinese navy in South China Sea. Retrieved November 3, 2019, from Reuters: https://ww w.reuters.com/article/us-china-defence/exclusive-satellite-im ages-reveal-show-of-force-by-chinese-navy-in-south-chi na-sea-idUSKBN1H3135

Saha, P. (2019, June 28). ASEAN's Indo-Pacific outlook: An analysis. Retrieved December 20, 2019, from Observer Research Foundation Online: https://www.orfonline.org/ex pert-speak/aseans-indo-pacific-outlook-an-analysis-52542/

Saiidi, U. (2018, February 7). Here's why the South China Sea is highly contested. Retrieved November 3, 2019, from CNBC News: https://www.cn bc.com/2018/02/07/heres-why-the-south-china-sea-is-high ly-contested.html

Sakaki, A. (2015). Japan's Security Policy: A Shift in Direction under Abe? Stiftung Wissenschaft und Politik Research Paper, 5-35.

Sato, Y. (2018, October 3). Japan versus China in the South China Sea. Retrieved July 6, 2019, from Asian Nikkei Review: https://asia.nikkei.com/Opinion/Japan-versus-Chi na-in-the-South-China-Sea

Shoji, T. (2014). The South China Sea: A View from Japan. NIDS Journal of Defense and Security, 127-141.

Shoji, T. (2015). Japan's Security Cooperation with ASEAN: Pursuit of a Status as a "Relevant" Partner. NIDS Journal of Defense and Security, 98-111.

Silverberg, E., \& Sullivan, M. (2019, October 29). Trump's IndoPacific strategy at year two. Retrieved December 24, 2019, from The Japan Times: https://www.japantimes.co.jp/opin ion/2019/10/29/commentary/world-commentary/trumps-in do-pacific-strategy-year-two/\#.XhQTBC2B2fQ

Stashwick, S. (2019, August 19). China's South China Sea Militarization Has Peaked. Retrieved December 20, 2019 ، from Foreign Policy: https://foreignpoli cy.com/2019/08/19/chinas-south-china-sea-militariza tion-has-peaked/

Storey, I. (2013). Japan's Growing Angst over the South China Sea. ISEAS Perspective, 1-11.

Storey, I. (2013). Japan's maritime security interests in Southeast Asia and the South China Sea dispute. Political Science, 135-156.

Szechenyi, N., \& Hosoya, Y. (2018). Working Toward a Free and Open Indo-Pacific. Alliance Policy Coordination Brief, 1-6.

The Department of Defense of United States of America. (2019) Indo-Pacific Strategy Report : Preparedness, Partnerships, and Promoting a Networked Region. The Department of Defense of United States of America.

The Guardian. (2020, June 27). ASEAN Leaders Cite 1982 UN Treaty in South China Sea Dispute. Retrieved July 22, 2020, from The Guardian: https://www.theguardi an.com/world/2020/jun/27/asean-leaders-cite-1982-un-trea ty-in-south-china-sea-dispute

Zhang, F. (2017). Chinese Thinking on the South China Sea and the Future of Regional Security. Political Science Quarterly, 435-466. 